\title{
COMMENTS ON PROFESSOR JOAN E. DONOGHUE'S ARTICLE, THE PUBLIC FACE OF PRIVATE INTERNATIONAL LAW: PROSPECTS FOR A CONVENTION ON FOREIGN STATE IMMUNITY
}

\author{
HORACE B. ROBERTSON, JR."
}

\section{INTRODUCTION}

As a commentator, one is usually expected to analyze a principal author's article, perhaps to bring new insights to the subject, and in most cases to point out areas in which the commentator might disagree with the author's analysis or conclusions and present counter-arguments and conclusions. I shall have to depart from that model in this comment, for I find myself in agreement with almost everything that Professor Donoghue has said in her excellent article. ${ }^{1}$ I am, however, intrigued by the subtle change of emphasis that Ms. Donoghue has provided for our discussion. The title given to our panel by the organizer of the symposium was "Foreign Sovereign Immunity: The Case for a New Treaty." Joan Donoghue's subtitle is "Prospects for a Convention on Foreign State Immunity." The hidden message I get from this subtitle, and it is borne out in the article, is that not much of a case can be made for a new treaty. If I read her correctly, she argues that, at least from the standpoint of advancing U.S. interests, now is an unpropitious time to attempt to move toward an international convention dealing generally with the substantive law of state immunity. She suggests that a small group of like-minded states (primarily European), including the newly liberated Eastern states that appear to be moving toward market economies, might achieve some common objectives in a convention that would focus primarily on procedural issues, ${ }^{2}$ perhaps along the lines suggested by Peter Trooboff in his Hague lectures in $1986 .{ }^{3}$ As she also points out, this is not what is really needed. Although there are some

Copyright $\odot 1994$ by Law and Contemporary Problems

* Professor of Law (Emeritus), Duke University School of Law.

In preparing this paper for publication, I have taken the liberty of incorporating comments on events occurring since its delivery in October 1992, in particular the report of the Open-Ended Working Group to the Sixth Committee of the United Nations General Assembly (Doc. A/C.6/47/L.10, 3 Nov. 1992) and the proceedings of the Sixth Committee in the 47th Session of the General Assembly.

1. Joan E. Donoghue, The Public Face of Private International Law: Prospects for a Convention on Foreign State Immunity, 57 LAW \& CONTEMP. PROBS. 305 (Summer 1994).

2. Id. at 319-21.

3. Peter D. Trooboff, Foreign State Immunity: Emerging Consensus on Principles, RECUIL DES COURS D'ACADEMIE DE DROIT INTERNATIONAL 235, 406 (1986). 
differences in the state immunity doctrines of these "like-minded states," the major differences in doctrine now occur between the industrialized "North" on the one hand and the developing "South" on the other, and, in the words of Ms. Donoghue, these disagreements are "no less contentious than the former EastWest polemics." 4 In my view, unless there is a reasonable prospect of resolving these differences, the prospects for, and the desirability of, supporting efforts to negotiate an international convention on state immunity are small.

II

\section{Negotiating PROBLEMS}

The difficulty is that even assuming that the principle of restrictive state immunity has replaced that of absolute immunity, ${ }^{5}$ the principle has no clearly defined content nor coherent rationale. ${ }^{6}$ From my experience in the law of the sea, I am reminded of the development of the concept of the exclusive economic zone ("EEZ"). Although it generally came to be recognized by the late 1970s, and certainly by the early 1980 s, that the concept of an EEZ had become a part of customary international law, ${ }^{7}$ it was not until the conclusion of the United Nations Convention on the Law of the Sea in $1982^{8}$ that the EEZ, one of the most important components of this Convention, was given a coherent identity and content. Although the maritime states and the territorialist states started out poles apart in negotiating the EEZ, they were ultimately able to reach agreement only because each side was willing to make concessions significant to the other in return for obtaining objectives significant to themselves. The maritime states were willing to accept coastal state jurisdiction over economic resources out to two hundred miles from the coast in return for stabilization of the limits of the territorial sea at twelve miles with guaranteed passage through international straits. ${ }^{9}$ For the present, at least, there seems to be no corresponding basis-no similar quid pro quo-for agreement on state immunity between North and South.

For any state, there are three prerequisites to successful international negotiations leading to a multilateral treaty. The first prerequisite is clearly defined negotiating objectives which the state hopes to achieve from the negotiations. The second prerequisite is a coherent strategy to attain these objectives. The third is a reasonable prospect of success in the negotiations. I

4. Donoghue, supra note 1 , at 322 .

5. This assumption is by no means universally accepted. See, e.g., IAN BROWNLIE, PRINCIPLES OF PUBLIC INTERNATIONAL LAW 330 (4th ed. 1990).

6. See James Crawford, Execution of Judgments and Foreign Sovereign Immunity, 75 AM. J. INT'L L. 820, 854-55 (1981).

7. See Barbara Kwiatkowska, The 200 Mile Exclusive ECONOMic Zone IN THE NEW LAW OF THE SEA 27-28 (1989) (and authorities cited therein).

8. United Nations Convention on the Law of the Sea, Dec. 10, 1982, official text contained in United Nations Publication Sales No. E.83.V.5 (1983). The Convention will enter into force on November 16,1994 , one year after the 60 th ratification was deposited.

9. See Tommy T.B. Koh, A Constitution for the Oceans, in THE LAw OF THE SEA: UNITED Nations Convention on THE LAW OF THE SEA xxxii (U.N. Sales No. E.83.V.5 1983). 
see problems for the United States in all three areas with respect to a universal agreement on state immunity.

As to the first, I can perceive no consensus in the United States as to what the objectives might be. There is a substantial gulf between the international business community and the private bar of the United States on the one hand and the national government on the other as to a number of issues concerning state immunity. The differences were illustrated in the positions of government and private witnesses in the hearings before the House and Senate on the American Bar Association proposals for amendments to the Foreign Sovereign Immunities Act (the "FSIA") in 1987 and 1988. ${ }^{10}$ In view of these differences, I doubt that the United States could come up with an agreed negotiating position on a number of issues that would be likely to succeed in an international negotiation. Although the Department of State could unilaterally establish a U.S. position, unless it was acceptable to the private bar, this action might create later difficulties in the ratification of any agreement reached.

As to the second prerequisite-a negotiating strategy-this is, of course, impossible without consensus on negotiating objectives, so I will leave this topic without further comment.

As to the third prerequisite-reasonable prospect of success-again, without clear-cut objectives, one cannot really estimate the odds of success. Assuming for the purpose of our discussion, however, that the U.S. goal would be to obtain an international agreement that resembles in major respects the FSIA, ${ }^{11}$ I see no reasonable prospect that such goals could be achieved. To illustrate, I will take several key provisions of the FSIA and contrast them with the provisions of the International Law Commission (the "ILC") draft articles on the same subject. ${ }^{12}$ Although there are other models for an international convention on sovereign immunity, ${ }^{13}$ the one most likely to serve as a model for an international negotiation is the ILC Draft Articles. Reflecting the

10. Foreign Sovereign Immunities Act: Hearings on H.R. 3763 Before the Senate Comm. on the Judiciary, 100th Cong., 2d Sess. (1988) [hereinafter Senate Hearings on H.R. 3763]; Foreign Sovereign Immunities Act: Hearings on H.R. 1149, H.R. 1689 and H.R. 1888 Before the Subcomm. on Administrative Law and Government Relations of the House Comm. on the Judiciary, 100th Cong., 1st Sess. (1987).

11. United States Foreign Sovereign Immunities Act, Pub. L. No. 94-583, 90 Stat. 2892 (1976) (codified as amended at 28 U.S.C. $\$ \S 1330,1391(\mathrm{~b}), 1441(\mathrm{~d}), 1602-1611$ (1988)) [hereinafter FSIA]. Although some provisions of the FSIA have engendered confusion in the courts and considerable criticisms and calls for reform among publicists (see, e.g., Donoghue, supra note 1, at 307-15), there is no consensus as to what form the changes should take. Some minor amendments have been made to FSIA since its enactment in 1976. Pub. L. No. 100-640, 102 Stat. 3333 (1988) (admiralty jurisdiction); Pub. L. No. 100-669, 102 Stat. 3969 (1988) (enforcement of commercial arbitration decisions); Pub. L. No. 101-650, 104 Stat. 5121 (1990) (technical amendments). But the basic substance and structure of the statute are unchanged, and major ambiguities and sources of confusion remain as originally enacted.

12. Draft Articles on Jurisdictional Immunities of States and Their Property: Report of the International Law Commission to the General Assembly, U.N. GAOR, 46th Sess., Supp. No. 10, U.N. Doc. A/46/10 (1991) [hereinafter 1991 ILC DRAFT ARTICLES].

13. See, e.g., European Convention on State Immunity, May 16, 1972, 11 I.L.M. 470 (1972); Organization of American States, Inter-American Draft Convention on Jurisdictional Immunity of States, Jan. 21, 1983, 22 I.L.M. 292 (1983); International Law Association, Draft Convention on State Immunity, Sept. 9, 1982, 22 I.L.M. 287 (1983). 
accommodations and compromises that were necessary in the Commission to get agreement on the text, the ILC draft will probably be the initial text which will establish the framework for any negotiation that may eventually occur.

\section{III}

\section{Problems WITH THE ILC DRaft CONVENTION}

In the Sixth Committee deliberations on the ILC Draft Articles in the 1991 Session of the General Assembly, of the twenty-six speakers who addressed the issue, an overwhelming majority (twenty) favored convening an international conference to negotiate an international convention on state immunity based on the ILC Draft Articles. Although the General Assembly, on the recommendation of the Sixth Committee, decided not to convene an international conference at that time, deciding instead to establish an "open-ended working group of the Sixth Committee" to examine further the issues of substance, such examination was to "facilitate a successful conclusion of a convention." 14 The report of this working group included a number of suggestions for substantive changes to the text of the ILC draft, which will be discussed below. But rather than recommending an early convening of an international conference on state immunity, the working group recommended setting aside two weeks ("at least ten to twelve meetings") at the start of the forty-eighth session of the General Assembly (1993-94) for additional concentrated work on substantive issues. ${ }^{15}$ As a result, the Sixth Committee recommended, and the General Assembly adopted, a decision which proposed the reestablishment of the Working Group during the forty-eighth session of the General Assembly "to continue consideration of the same issues in order to facilitate the successful conclusion of a convention through the promotion of general agreement."16

\section{IV}

\section{DIFFERENCES BETWEEN THE ILC DRAFT CONVENTION AND THE FSIA}

First among the differences between the FSIA and the ILC Draft Articles are their approaches to what constitutes a commercial activity. The FSIA provides that whether a governmental activity is commercial or noncommercial is to be determined by the nature of the activity and not its purpose. Although there had been some wavering from this standard among lower federal courts, the recent decision of the United States Supreme Court in Republic of

14. Report of the International Law Commission on the Work of Its Forty-Third Session, U.N. GAOR, 6th Comm., 43d Sess., at 2, U.N. Doc. A/C.6/46/L.15 (1991).

15. Report of the Working Group on Convention on Jurisdictional Immunities of States and Their Property, U.N. GAOR, 6th Comm., at 8, U.N. Doc. A/C.6/47/L.10 (1992) [hereinafter WORKING GROUP REPORT].

16. Report of the Sixth Committee on Convention on Jurisdictional Immunities of States and Their Property, U.N. GAOR, 6th Comm., at 3, U.N. Doc. A/47/585 (1992). Resolutions and Decisions Adopted by the General Assembly During its Forty-Seventh Session, U.N. GAOR, 6th Comm., 43d Sess., at 106, U.N. Doc. A/INF./47/8 (1992). 
Argentina $v$. Weltover, Inc., ${ }^{17}$ has reined in the lower courts on this issue. It is now clear that the U.S. doctrine on this issue, as laid out in the FSIA and as interpreted by the Supreme Court, is that the nature of the act rather than its purpose governs. The ILC draft, on the other hand, provides:

In determining whether a contract or transaction is a 'commercial transaction' ... reference should be made primarily to the nature of the contract or transaction, but its purpose should also be taken into account if, in the practice of the State which is a party to it, that purpose is relevant to determining the non-commercial character of the contract or transaction. ${ }^{18}$

In its comment on this paragraph, the ILC explains that this two-pronged test was adopted "to provide an adequate safeguard and protection for developing countries, especially in their endeavours to promote national economic development."19 As examples of when the purpose of the transaction might govern, transforming a transaction that on its face is commercial to one that is sovereign (and thus immune), the ILC mentions "the procurement of food supplies to feed a population, relieve a famine situation or revitalize a vulnerable area, or supply medicaments to combat a spreading epidemic, provided that it is the practice of that State to conclude such contracts or transactions for such public ends." ${ }^{20}$ Under this test and by analogy to these examples, almost any transaction could be held to be noncommercial, since no state purports to act except for "public ends."

Recognizing the potential that the ILC draft had for "subjective interpretations as to the practice of the defendant State" and for the purpose of "reducing the risk that private parties might be placed in an uncertain and disadvantageous position," the Working Group Report recommended that the provision now contained in the commentary be incorporated into the text of paragraph 2 of article 2 itself as follows:

In determining whether a contract or transaction is a commercial transaction under paragraph 1 (c), reference should be made primarily to the nature of the contract or transaction, but in the exceptional circumstances where the contract or transaction is made for the purpose of humanitarian assistance including the procurement of food supplies to relieve a famine situation or the supply of medicaments to combat a spreading epidemic, such a contract or transaction may be regarded as non-commercial. $^{21}$

According to the Working Group Report, the proposed reformulation would give "less leeway" for subjective interpretations. ${ }^{22}$ Whether this change would have the predicted effect is open to debate since the use of the word "including" seems to leave the list merely illustrative and open-ended.

Despite the difficulties in applying the "nature of the transaction" test (and Professor Donoghue has referred to them in her principal article and developed

17. 112 S. Ct. 2160 (1992). See also Saudi Arabia v. Nelson, 113 S. Ct. 1471 (1993).

18. 1991 ILC DRAFT ARTICLES, supra note 12, art. 2, II 2.

19. Id. at 30 (commentary).

20. Id.

21. WORKING GROUP REPORT, supra note 15 , at 4 .

22. Id. 
them in more detail in her recent Yale Journal of International Law article ${ }^{23}$ ), that test is firmly embedded in U.S. statutory law and departure from it would undermine one of the main features of that law.

The so-called "nexus" issue is a second area of difference. Both the FSIA and the ILC draft require a certain nexus between the act or activity upon which a suit is based and the forum state in order to create an exception to the immunity of the foreign state. This "nexus" requirement is explicit in the torts provisions of both instruments, but only the FSIA makes this requirement explicit with respect to the commercial transaction exception to immunity.

With respect to tort liability, the. FSIA provides that the foreign state shall not be immune in cases of personal injury or death, or damage to or loss of property "occurring in the United States." ${ }^{24}$ Under this provision, the injury or harm must be suffered in the United States, although the statute is silent as to whether the tortious act or omission must also take place in the territory of the United States. Relying on the legislative history, ${ }^{25}$ three federal courts of appeals have held that the tortious act or omission must also have taken place in the United States. ${ }^{26}$ The Restatement (Third) of the Foreign Relations Law of the United States takes the position that only the injury must take place in the United States; the tortious act or omission may occur elsewhere provided the injury is a direct result of the tortious act or omission. ${ }^{27}$ The ILC draft requires explicitly that the act or omission occur "in whole or in part in the territory of [the forum State] and [that] the author of the act or omission [be] present in that territory at the time of the act or omission." 28 This difference in approach is unlikely to be resolved in an international negotiation because the sentiment in the United States seems to be for loosening rather than tightening the required nexus between the territory of the forum state and the wrongful act or resulting harm. ${ }^{29}$ In the Working Group of the Sixth Committee, there was some sentiment for deleting article 12 in its entirety, ${ }^{30}$ but the nexus question was not addressed.

23. Joan E. Donoghue, Taking the "Sovereign" out of the Foreign Sovereign Immunities Act: A Functional Approach to the Commercial Activity Exception, 17 YALE J. INT'L L. 489, 499-512 (1992).

24. FSIA, supra note $11, \S 1605(\mathrm{a})(5)$.

25. H.R. REP. No. 1487, 94th Cong., 2d Sess. 21 (1976); S. REP. No. 1310, 94th Cong., 2d Sess. 21 (1976), reprinted in 1976 U.S.C.C.A.N. 6604, 6619.

26. Frolova v. U.S.S.R., 761 F.2d 370 (7th Cir. 1985); Olsen by Sheldon v. Mex., 729 F.2d 641 (9th Cir.), cert. denied, 469 U.S. 917 (1984); Persinger v. Islamic Republic of Iran, 729 F.2d 835 (D.C. Cir.), cert. denied, 469 U.S. 881 (1984).

27. RESTATEMENT (THIRD) OF THE FOREIGN RELATIONS LAW OF THE UNITED STATES $§ 454 \mathrm{cmt}$. e, r.n. 1 (1987).

28. 1991 ILC DRAFT ARTICLES, supra note 12, art. 12. The immunity acts of the United Kingdom, Canada, and Australia, as well as the European Convention, also explicitly require that the tortious act or omission occur within the forum state. See State Immunity Act, 1978, ch. 33, $\$ 5$ (U.K.), reprinted in 17 I.L.M. 1123, 1125 (1978) [hereinafter U.K. Immunity Act; Act to Provide for State Immunity in Canadian Courts, July 15, 1982, ch. 95, $\$ 6$ (Can.), reprinted in 21 I.L.M. 798, 799 (1985) [hereinafter Canadian Immunity Act]; Foreign States Immunities Act, 1985, Dec. 16, 1985, $\S 13$ (Austl.), reprinted in 25 I.L.M. 715, 719 (1986) [hereinafter Australian Immunities Act]; European Convention on State Immunity, supra note 13 , art. 11.

29. See Donoghue, supra note 1 , at 311 n.25.

30. WORKING GROUP REPORT, supra note 15 , at 17. 
For commercial transactions, the FSIA's provision is similar to traditional U.S. law as to the exercise of long-arm jurisdiction over absent defendants, providing that the foreign state shall not be immune as to "a commercial activity carried on in the United States by the foreign state; or upon an act performed in the United States in connection with a commercial activity of the foreign state elsewhere; or upon an act outside the territory of the United States in connection with a commercial activity of the foreign state elsewhere and that act causes a direct effect in the United States." 31 This provision, when tied to the first section of the FSIA, ${ }^{32}$ which links personal jurisdiction to a determination that the defendant state is not immune under the Act, is one of the most ambiguous and confusing aspects of the U.S. statutory scheme. The ILC provision, on the other hand, has no explicit nexus provision, leaving that to the determination of the court's jurisdiction under the "applicable rules of private international law." 33 The Commentary to Article 10 explains this provision:

It is common ground among the various approaches to the study of State immunities that there must be a pre-existing jurisdiction in the courts of the foreign State before the possibility of its exercise arises and that such jurisdiction can only exist and its exercise only be authorized in conformity with the internal law of the State of the forum, including the applicable rules of jurisdiction, particularly where there is a foreign element involved in a dispute or differences that require settlement or adjudication. $^{34}$

Although my personal view is that the ILC approach is the preferable one and would certainly be an improvement over the muddled U.S. statute, it is questionable whether this change would be acceptable to the United States.

The third and final problem I shall mention is that of enforcement. It is probably here that there is the greatest difference between the approaches of the United States and a number of other states, particularly developing ones. I think it is common ground that there is a difference between denying immunity to a foreign state in order to adjudicate a controversy between a private person and that state on the one hand and the seizure of or execution upon that state's property either before or after a judgment on the other. (The ILC draft refers to these measures as "measures of constraint." ${ }^{35}$ ) All of the national statutes I have examined have recognized this dichotomy. ${ }^{36}$ Until the adoption of the FSIA, U.S. law did not allow any execution upon foreign state property following judgment but did, under certain circumstances, allow

31. FSIA, supra note $11, \S 1605(\mathrm{a})(2)$.

32. Id. § 1330 .

33. 1991 ILC DRAFT ARTICLES, supra note 12, art. 10, 1.

34. Id. art. 10, II 4 (commentary).

35. Id. art. 10.

36. FSIA, supra note 11, §1609; U.K. Immunity Act, supra note 28, §13(1)(b); Canadaian Immunity Act, supra note 28, \& 11; Australian Immunities Act, supra note 28, pt. IV. For a comprehensive review of state legislation and practice, see ILC Special Rapporteur, Seventh Report on Jurisdictional Immunities of States and Their Property, Jurisdictional Immunities of States and Their Property, U.N. Doc. A/CN.4/388, 99 47-64 (1985), reprinted in 21985 YEARBOOK OF THE INTERNATIONAL LAW COMMISSION 31-33 (1985) (Part I). 
attachment of property for purposes of in rem jurisdiction. ${ }^{37}$ The FSIA reversed that scheme, allowing prejudgment attachment only with the explicit consent of the foreign state, but allowing execution on certain categories of foreign state property to satisfy a judgment. ${ }^{38}$ As evidenced by the 1988 hearings on amendments to the FSIA, there is significant support in the United States for broadening the types of property subject to such execution. ${ }^{39}$ On the other hand, the ILC draft, reflecting primarily the sensitivities of the developing states and their extreme concern with protection of their "sovereign" rights, takes a much more conservative position on "measures of constraint." Its provisions, which apply both to pretrial and prejudgment restraint as well as to measures in satisfaction of a judgment, allow attachment, arrest, or execution of government property in only three circumstances: (1) where the state has expressly consented; (2) where the state has allocated or earmarked property for the satisfaction of the claim which is the subject of the proceeding; or (3) where the property is "specifically in use or intended for use by the State for other than government noncommercial purposes and is in the territory of the State of the forum and has a connection with the claim which is the object of the proceeding or with the agency or instrumentality against which the proceeding was directed." 40 These narrow exceptions to immunity from execution are unlikely to satisfy U.S. interests, and any departure from them is likely to be strongly opposed by developing states.

It should be noted, however, that the Open-Ended Working Group to the Sixth Committee recognized the extreme narrowness of the ILC provision on measures of constraint and made certain proposals for modification which it said were "intended to strike a balance between the position of those for whom only commercial State property having a link with the underlying claim or with the agency or instrumentality concerned should be subject to measures of constraint and the position of those who object to the requirement of such a link."

\section{$\mathrm{V}$ \\ CONCLUSION}

There are, of course, other controversial provisions in the ILC Draft Articles. I have selected only three issues for discussion in view of their importance to the overall scheme set forth in the articles. Should an international negotiation eventually occur, I am sure that these issues will pose significant difficulties to the successful conclusion of a generally acceptable agreement. On the other hand, if no international negotiations for a treaty on foreign state immunity take place-as Ms. Donoghue suggests is the more likely

37. United States Foreign Sovereign Immunities Act, H. REP. No. 1487, 94th Cong., 2d Sess. 26 (1976), reprinted in 1976 U.S.C.C.A.N. 6604, 6626.

38. FSIA, supra note $11, \S 1610$.

39. See Senate Hearings on H.R. 3763, supra note 10.

40. 1991 ILC DRAFT ARTICLES, supra note 12, art. 18, II 1.

41. WORKING GROUP REPORT, supra note 15 , at $5,12$. 
outcome of current discussions-these same issues will undoubtedly continue to simmer as states continue their differing practices as to questions of state immunity. 
